Rocha, Herivelto Fernandes. Disputa territorial, conceitualização e atualidade da Reforma Agrária no Brasil. GeoGraphos. [En línea]. Alicante: Grupo Interdisciplinario de Estudios Críticos y de América Latina (GIECRYAL) de la Universidad de Alicante, 28 de marzo de 2013, vol. 4, n 50, p. 433-462 . [ISSN: 2173-1276].

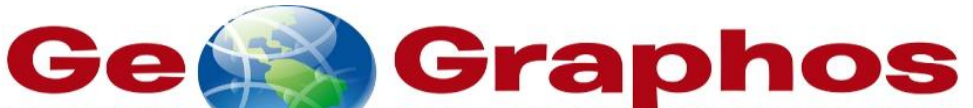

\title{
DISPUTA TERRITORIAL, CONCEITUALIZAÇÃO E ATUALIDADE DA REFORMA AGRÁRIA NO BRASIL
}

\author{
Herivelto Fernandes Rocha \\ Mestrando do Programa de Pós-Graduação em Geografia \\ Faculdade de Ciências e Tecnologia - FCT - UNESP \\ Pesquisador do Núcleo de Estudos, Pesquisas e Projetos de Reforma Agrária - NERA \\ Presidente Prudente, São Paulo, Brasil \\ Correo electrónico: herivelto_tom@yahoo.com.br
}

Recibido: 19 de febrero de 2013. Devuelto para revisión: 15 de marzo de 2013.

Aceptado: 28 de marzo de 2013

\section{RESUMO}

A questão Agrária, ou seja, os problemas agrários gerados pela expansão e reprodução ampliada do capitalismo no campo, no Brasil está intrinsecamente relacionada com a conflitualidade entre diferentes modelos de desenvolvimento que disputam o controle territorial do país. Na primeira parte deste trabalho apresentamos uma análise da conceitualização da Reforma Agrária, tomando como base os trabalho dos principais autores que trataram do tema, e os resultados da implementação desta política pública no Brasil, entre os anos de 1985 e 2010. Na segunda parte realizamos uma leitura sobre a disputa territorial entre o agronegócio, representado pelo paradigma do Capitalismo Agrário, e o campesinato, representado pelo paradigma da Questão Agrária. 
Palavras-chave: Paradigma, Agronegócio, Campesinato, Reforma Agrária.

\title{
DISPUTA TERRITORIAL CONCEPTUALIZACIÓN Y LA ATUALIDADE DE LA REFORMA AGRARIA EN BRASIL
}

\section{RESUMEN}

La cuestión agraria, es decir, los problemas agrarios generados por la expansión y la reproducción ampliada del capitalismo en el campo, en Brasil está estrechamente vinculado al conflicto entre diferentes modelos de desarrollo que compiten por el control territorial del país. En la primera parte de este trabajo se presenta un análisis de la conceptualización de la Reforma Agraria, basada en la obra de autores que abordaron el tema, y los resultados de la aplicación de esta política en Brasil entre 1985 y 2010. En la segunda parte se realiza una lectura sobre la disputa territorial entre el agronegócio, representada por el paradigma del capitalismo agrario, y de los campesinos, representada por el paradigma de la cuestión agraria.

Palabras clave: Paradigma, Agronegócio, Campesinos, Reforma Agraria.

\section{TERRITORIAL DISPUTES CONCEPTUALIZATION AND TIMELINESS OF LAND REFORM IN BRAZIL}

\begin{abstract}
In Brazil, the agrarian question, understood as the agrarian problems resulting from the continued expansion and reproduction of capitalism in the countryside, is inextricably linked to the conflict between different development models vying for territorial control of the country. The first part of this paper provides an analysis of the conceptualization of agrarian reform, based on the work of some of the principle authors who have studied the issue, and the results of implementing agrarian reform policy in Brazil between 1985 and 2010. This is followed by a discussion of the ongoing territorial dispute between agribusiness, represented by the paradigm of Agrarian Capitalism, and the peasantry, represented by the Agrarian Question paradigm.
\end{abstract}

Keywords: Paradigm, Agribusiness, Peasantry, Agrarian Reform.

\section{INTRODUÇÃO}

No presente artigo propomos uma reflexão sobre o conceito de Reforma Agrária e sobre a disputa territorial pelos diferentes modelos de desenvolvimento do campo brasileiro. O debate sobre a conceitualização, atualidade e sentido da Reforma agrária vem sendo realizado no NERA Núcleo de Estudos, Pesquisas e Projetos de Reforma Agrária desde 2008, onde propomos uma releitura deste conceito, sobretudo no Brasil, diante dos novos elementos que compõe a Questão Agrária Brasileira (Fernandes, Welch e Gonçalves, 2012; Oliveira, 2011; Cubas, 2012; Bombardini, 2012) somados a diversidade da política de Reforma Agrária implantada no país ao longo do século XX e inicio do século XXI (políticas de obtenção de terras e tipologia dos 
assentamentos). Temos no Brasil, de acordo com o DATALUTA (2012), 11 políticas de obtenção de terras e 20 tipos de assentamentos rurais. O debate atual da Reforma Agrária no Brasil, está centrado na questão da necessidades deste processo e a forma com que ele foi implementado no país nas últimas décadas. Acadêmicos, instituições e movimentos socioterritoriais defendem o ponto de vista de acordo com o paradigma aos quais são filiados. Fernandes, Welch e Constatino nos explicam que:

[...] os paradigmas representam as visões de mundo, que contém interesses e ideologias, desejos e determinações, que se materializam através de políticas públicas nos territórios de acordo com as pretensões das classes sociais. Através do recurso paradigmático, os cientistas interpretam as realidades e procuram explicá-las (Fernandes, Welch e Gonçalves, 2012, p.29).

No campo brasileiro temos duas correntes paradigmáticas predominantes. O Paradigma da Questão Agrária (PQA) que tem "como ponto de partida as lutas de classes para explicar as disputas territoriais e suas conflitualidades na defesa de modelos de desenvolvimento que viabilize autonomia dos camponeses" (Fernandes, Welch e Gonçalves, 2012, p. 29) e o Paradigma do Capitalismo Agrário (PCA) que nega a existência da Questão agrária, neste paradigma a compreensão predominante é de que "as desigualdades geradas pelas relações capitalistas são um problema conjuntural e pode ser superado por meio de políticas que possibilitem a "integração" do campesinato ou "agricultor de base familiar" ao mercado capitalista" (Fernandes, Welch e Gonçalves, 2012, p. 29-30).

Na primeira parte do nosso trabalho apresentamos uma análise dos principais teóricos que se debruçaram ao longo do século XX sobre a questão da Reforma Agrária, destacamos também uma análise atual dos principais interlocutores dos paradigmas, que disputam o território no Brasil e por fim uma análise da Reforma Agrária implantada pelos governos brasileiros ao longo do século XX.

Na segunda parte destacamos, uma breve leitura sobre, a disputa territorial entre o agronegócio e o campesinato, e sua territorialização no Brasil.

\section{CONCEITUALIZAÇÃO DA REFORMA AGRÁRIA}

Qué se reforma, cómo se reforma y para qué se reforma (García, 1973).

Nesta parte, discutimos a conceitualização da Reforma agrária ao analisarmos algumas obras, consideradas relevantes, de estudiosos que se debruçaram sobre esta questão. Muitos autores, sobretudo ao longo do século XX, discorreram em seus trabalhos sobre o tema da Reforma Agrária e os impactos de alguns processos reformistas que ocorreram pelo mundo. Apresentamos também, um quadro onde sistematizamos informações sobre os processos de Reforma Agrária, ocorridos em países espalhados pelo mundo ao longo do século XX. Neste quadro esboçamos uma classificação destas Reformas com base na revisão bibliográfica que fizemos sobre o tema. 
O sociólogo colombiano Antonio García discutiu em duas obras (1967 e 1970) o processo de Reforma Agrária na America Latina. No livro publicado em 1967 intitulado "Dinamica de las reformas agrárias en América latina", com o apoio do ICIRA, Garcia defendeu uma ruptura com as teorias ocidentais referentes à conceitualização da Reforma Agrária, que eram, em sua grande maioria, fundamentadas em noções tecnocráticas de mudança ou em ideologias das nações industrializadas, capitalista ou socialista. Para Antonio García, a leitura feita nos países industrializados não condizia, na maioria dos casos, com a realidade latino americana, o autor entende que:

Casi todos los esquemas ocidentales se basan en supuestos como el de que ha sido superado el ciclo de la "sociedad colonia" y de las relaciones señoriales, y el de que la estructura latifundista clásica ha sido reemplazada por una estructura abierta, integrada y de grandes espacios. La preocupación de los teóricos europeos o norteamericanos por asignar al pago de indemnizaciones la naturaleza de núcleo esencial de la reforma agrária, presupone el que hayan desaparecido las antiguas formas del monopolio señorial sobre la propiedad de la tierra, el agua y los bosques, y el que funcionen, realmente, un mercado de tierras como mecanismo redistribuidor de los recursos físicos y un mercado de trabajo rural como mecanismo redistribuidor de los ingresos agrícolas. De otra parte, los enfoques tecnológicos se orientan en el sentido de diseñar tipos perfeccionistas de "reformas agrarias integrales" (en la que, al decir de una economista inglesa, parece darse todo a los campesinos menos la tierra) o en el de sustituir la reforma agraria por políticas keynesianas o "funcionales" de desarrollo agrícola (estímulos a la inversión, mejoramiento de las tecnologías, manejo de mecanismos tributarios, subvención pública a los propósitos innovadores de la productividad rural) (García, 1967, p. 1).

Neste sentido, a conceitualização da Reforma Agrária deveria valorizar e ter como ponto de partida a experiência latino-americana e não apenas as experiências ocorridas em outros países, como se a Reforma Agrária fosse um "enlatado qualquer", que pode ser utilizado independente do contexto e de fatores históricos de formação econômica e política. Garcia defende que a Reforma Agrária deve ser entendida:

[...] como operación estratégica de desarrollo económico y social de las naciones atrasadas y no sólo como política de justicia social, como expresión agrarista del "hambre campesina de tierras", como aspiración burguesa a una economía de mercado o como proyecto tecnocrático de reemplazar, artificialmente y sin cambios estructurales, la sociedad tradicional latinoamericana por una "sociedad industrial de modelo norteamericano o europeo” (García, 1967, p. 3).

Em 1970 García publicou o livro sobre a "Sociologia de la reforma agrária en la América Latina" em que sistematizou a Reforma Agrária em três grandes categorias. A primeira tratou da Reforma Agrária Estrutural, baseada num processo reformista revolucionário liderado por novas forças sociais, fundamentada na modificação radical das relações de poder de um determinada sociedade e nas normas institucionais que as sustentavam. A segunda categoria diz respeito à Reforma 
Agrária Convencional, baseada em uma operação negociada entre antigas e novas forças sociais, objetivando modificar o funcionamento da estrutura agrária, sem grandes mudanças nas normas institucionais da sociedade tradicional. A terceira categoria abordou a Reforma Agrária Marginal ou Contra-Reforma Agrária, que objetiva manter o monopólio sobre a terra ou sobre as estruturas fundiárias promovendo uma reparação superficial, desviando a pressão dos movimentos socioterritoriais de luta pela terra.

Outro autor, ainda na década de 1970, a se debruçar sobre o tema foi o economista Peter Dorner relacionou a Reforma Agrária ao processo de desenvolvimento. Em seu livro "Reforma agrária e desenvolvimento econômico" Dorner analisou a Reforma Agrária e as estratégias de desenvolvimento que devem estar atreladas ao processo reformista. Para ele a "Reforma Agrária tem um significado profundo, essencial, que abrange alterações significativas e intencionais da posse da terra - modificações da propriedade e controle da terra e dos recursos hídricos" (Dorner, 1972, p. 21). O autor desta que apesar da Reforma Agrária ser elemento fundamental para as estratégias de desenvolvimento, ela ganhou mais importância após o término da Segunda Guerra Mundial, período que coincide com inicio das políticas desenvolvimentistas de meados do século XX, sobretudo, nos países em desenvolvimento:

[...] a Reforma Agrária, como problema de desenvolvimento explicito e estratégico, tornou-se mais proeminentes nas últimas décadas. O fim da Segunda Guerra Mundial assinalou o começo de uma era nova. Muitos países obtiveram independência política nas duas décadas que se seguiram ao termo da guerra. O colonialismo desmoronou-se, e as antigas potências iniciaram um desmantelamento de impérios em grande escala. Formaram-se governos nacionais novos, independentes do domínio estrangeiro, que colocaram o desenvolvimento interno entre os primeiros problemas a atacar. Foi esta a fase inicial daquilo que é agora coisa corrente - planos nacionais para participação ativa do Governo no estimulo do desenvolvimento econômico (Dorner, 1972, p. 26).

Mesmo com a importância dada, a Reforma Agrária encontrou inúmeros obstáculos em sua implementação, para Dorner o principal entrave à instauração do processo reformista esta relacionado a ligação existente entre os interesses econômicos e políticos com os interesses agrários, esta ligação "é um dos mais fortes obstáculos com os quais depara a reforma agrária, reforma que implica inevitavelmente decisões políticas drásticas e confrontações de várias ordens" (Dorner, 1972, p. 36).

Outros autores trataram da Reforma Agrária ao analisarem as experiências reformistas em alguns países do mundo. Nestes trabalhos, alguns deles conceitualizaram e defenderam seus respectivos pontos de vista em relação à Reforma Agrária. Fernando Sanz-Pastor (1988) ao tratar da necessidade de uma Reforma Agrária na Espanha, de meados do século XX, explica que ela "está, em geral, ligada ao conceito de revolução camponesa" (Sanz-Pastor, 1988 p.11). Para ele o advento da "Revolução Verde" e "a implantação de moderna maquinaria, novas técnicas, sementes selecionadas, adubos, tratamentos fito-sanitários, etc., tem provocado mudanças profundas no velho conceito de 'a terra para quem nela trabalha" (Sanz-Pastor, 1988 p.12), ou seja, para Sanz-Pastor, qualquer "reivindicação atual por Reforma Agrária deve levar em 
consideração esta nova situação, mesmo reconhecendo que nos países subdesenvolvidos tenha que se pensar primeiramente em dar trabalho à enorme população ativa, que ainda permanece no campo" (Sanz-Pastor, 1988, p. 12). O autor entende ainda que a "velha e clássica Reforma Agrária foi superada pela chamada Revolução Verde. Seus princípios podem ser aplicáveis, como primeiro passo, em países subdesenvolvidos com uma grande concentração da terra em poucas mãos" (Sanz-Pastor, 1988, p. 14). Esta visão apresentada por Sanz-Pastor é favorável a uma corrente ideológica que entende que o problema da Reforma Agrária já está superado e que basta, apenas, a adequação dos camponeses marginalizados a esta lógica "modernizante" - em maior ou menos grau nos países tidos como desenvolvidos e nos países considerados subdesenvolvidos -, para que consigam se inserir neste sistema "moderno" sanando seus problemas e dificuldades.

Cláudio Thomaz Bornstein (1982) em sua obra intitulada "A Reforma Agrária na Nicarágua", apresenta uma visão contrária a defendida por Sanz-Pastor, ele entende que uma "Reforma Agrária evidentemente não pode ser isolada de um contexto mais geral relativo ao estágio de desenvolvimento da sociedade na qual ela se insere" (Bornstein, 1982, p. 56) e que "A Reforma agrária é questão complexa e requer todo o cuidado para evitar generalizações, regras fixas e inflexíveis ou soluções simplistas" (Bornstein, 1982, p. 75). Um raciocínio interessante deste autor é de que "nem todos os aspectos de uma reforma agrária podem ser expressos em uma lei. Por exemplo, uma reforma agrária inclui também infraestrutura no campo, o que significa dar créditos, montar uma estrutura de transporte, armazenagens e comercialização do produto, difundir técnicas modernas de plantio, permitir a aplicação de insumos modernos, mecanização e etc." (Bornstein, 1982, p.77), ou seja, a Reforma Agrária além de estar garantida no âmbito legal, das regras institucionais de uma dada sociedade, necessita ser acompanhada de políticas públicas que garantam o desenvolvimento de seus beneficiários.

No Brasil, José Gomes da Silva, em sua obra “A Reforma Agrária no Brasil” (1971), tratou, além de muitos outros fatores, da conceitualização da Reforma Agrária. Para ele a reforma deve responder "aos enunciados básicos de um bom conceito (que, quando, quanto, onde, como, quem) (Silva, 1971, p. 37)". Neste trabalho o autor sistematizou três tipos possíveis de transformações que podem acarretar em melhoramentos para o setor agrícola, são elas: simples instrumentos de política; modificações nas estruturas existentes; e modificações das estruturas existentes.

Para ele os instrumentos políticos "raramente conduzem a qualquer transformação substancial" (Silva, 1971, p. 18) e se referem a mudanças quantitativas como, por exemplo, aumento de impostos, crédito e subsídios. Em relação às modificações nas estruturas, "o status quo permanece, verificando-se apenas alterações de maior ou menor profundidade" (Silva, 1971, p. 18) e nas reformas ou mudança das estruturas se faz necessário" a troca dos sistemas vigentes por outros, como é o caso da modificação do regime de posse e uso da terra, da introdução da agricultura de grupos e etc." (Silva, 1971, p. 18). Sobre estas tipologias ele complementa dizendo que:

Um exemplo concreto permitirá estabelecer o claro divisor de águas que existe entre as gradações de políticas agrícolas: a redução da taxa de juro para o financiamento de adubos seria um mero instrumento de política; a introdução de um sistema de financiamento integral constituiria uma mudança na estrutura que regulamenta a utilização desse importante insumo agrícola; a 
nacionalização da indústria de adubos representaria uma reforma (Silva, 1971, p. 19).

Silva define a Reforma Agrária como um "processo amplo, imediato e drástico de redistribuição de direitos sobre a propriedade privada da terra agrícola, promovido pelo Governo, com a ativa participação dos próprios camponeses e objetivando sua promoção humana, social, econômica e política" (Silva, 1971, p. 37). Ou seja, a Reforma Agrária deve, necessariamente, ter como base a terceira tipologia apresentada, que é baseada em mudanças das estruturas sociais vigentes. Portanto, a modificação ocasionada:

[...] pela Reforma Agrária necessita ser drástica, isto é, a 'agricultura reformada' precisa apresentar características estruturais totalmente diferentes do status quo há pouco modificado e não apenas constituir uma tênue e transitória concessão para acalmar a inquietação camponesa porventura reinante na ocasião" (Silva, 1971, p. 39).

O autor, ainda faz uma ressalva de que em uma:

Reforma Agrária democrática, a posse da terra não pode constituir uma imposição de políticos no poder, ou resultar de esquemas econômicos elucubrados pela tecnocracia dominante. Tampouco deve representar um mero presente do Estado ao "homem sem terra" ou com terra insuficiente. Deve, isso sim, ser planejada, desencadeada e conduzida, em todas as suas fases e etapas, com a ativa e constante participação dos futuros parceleiros (Silva, 1971, p. 40).

Esta leitura de Silva é compatível ao apresentado por Bornstein na análise do caso nicaraguense. Por isso, fica claro, que não basta nos antevermos a uma única dimensão ou um único setor (político, produtivo, econômico), na aplicação de uma política de Reforma Agrária, devemos nos atentar a um conjunto de fatores que se somados podem fazer do processo reformista uma operação de sucesso.

Outro autor brasileiro que se debruçou sobre o tema, foi Gileno de Carli, em sua obra a "História da Reforma Agrária" (Carli, 1985). Neste trabalho, ele faz uma análise de experiências ocorridas em alguns países ${ }^{1}$. Carli, assim como García, é contrário a adoção de "esquemas prontos" relativos a implementação da Reforma Agrária. Para ele:

Seria uma estultice querer transplantar para o Brasil uma reforma agrária adotada em qualquer outro país, como um remédio para as dificuldades que nos são peculiares, com estruturas diferentes, mentalidades diversas, com grau de conhecimento técnico distanciado para mais ou para menos, com relações demográficas as mais variadas, com climas os mais diferentes, com típicas economias regionais. Áreas muito secas, zonas muito úmidas, centros altamente

\footnotetext{
${ }^{1}$ Carli analisa os processos de Reforma Agrária ocorridos na China, em Cuba, no México e na Itália.
} 
concentrados, populações de alto como de baixo consumo, produtividade diferenciada, solos, desertos, regimes de trabalho. Uma área continental. Problemas não de um só pais, mais de vários mundos, dentro de uma unidade política que atravessou os tempos de todas as vicissitudes (Carli, 1985, p. 135).

Carli defende que a Reforma Agrária no Brasil deva ter como base de sustentação uma série de "providencias legislativas", para que essa reforma seja alcançada de forma pacífica, como, por exemplo, a) uma lei de acesso a terra; b) uma lei de arrendamento e parceria; c) uma lei sobre crédito agrícola; d) uma lei de organização rural; e) uma lei de irrigação; f) uma lei de sobre ensino rural. Esta visão de Carli ignora, em grande parte, a conflitualidade existente no campo brasileiro, onde a correlação de forças contrárias (que exercem o controle político e econômico do Estado) à Reforma Agrária não permitiria a realização de uma reforma a partir de tais modificações. Carli, apesar do conhecimento da causa, trata o tema de forma simplista, ignorando outras dimensões do território e a necessidade de pensarmos a Reforma Agrária como uma questão estrutural que deve ser acompanhada, planejada e gerida pelo Estado em consonância com a sociedade e os beneficiários deste processo.

\section{EXPERIÊNCIAS DE REFORMA AGRÁRIA AO LONGO DO SÉCULO XX}

Ao longo do século XX vários países do mundo implementaram uma diversidade de processos de Reformas Agrárias. Na Europa o caso mais relevante ocorreu na Rússia, onde tivemos dois processos distintos de Reforma Agrária. A primeira foi realizada nos tempos no final do século XIX, na época do Czar, e a segunda foi precedida pela revolução socialista comandada pelos bolcheviques. Sanz-Pastor destaca que "em 1861, nos tempos do Czar Alexandre II, a servidão foi abolida, ao mesmo tempo em que se implantou uma importante Reforma Agrária [...] Para isso se estabeleceu um compromisso, mediante o qual o camponês devia pagar pelo fim de sua condição de servo e ao mesmo tempo recebia um pedaço de terra" (Sanz-Pastor, 1988, p. 20).

Este processo, mesmo considerado avançado para a época, culminou com endividamento dos antigos servos. O Estado financiava $80 \%$ do valor da terra e os servos eram obrigados, com investimentos próprios, a custear o restante. Sanz-Pastor defende que "O resultado desta reforma foi o mesmo que armar uma bomba relógio, que cedo ou tarde teria que explodir, já que não há coisa pior que empreender uma reforma, iludindo as pessoas, e então deixar esta reforma a meio caminho" (Sanz-Pastor, 1988, p. 21).

Uma consequência deste processo, de endividamento dos camponeses, foi o fortalecimento das comunas ou mir, que eram um misto de propriedade individual e uso coletivo do solo. As famílias possuíam, em regime de propriedade privada um lote pequeno, a área restante era distribuída pelo conselho comunitário de acordo com o tamanho, capacidade de trabalho e a necessidade das famílias (Abramovay 1990, p. 48). O governo Russo, preocupado com o avanço e fortalecimento das comunas, que já estavam se territorializando sobre as terras pertencentes a nobreza. Decidiu interferir neste processo, Sanz-Pastor destaca que:

O Governo, ao se dar conta disto, procurou destruir a estrutura comunal, dando direito aos camponeses de adquirir, em propriedade plena e com uma única parcela, as terras das comunas que estivessem explorando. Com isto buscou-se 
criar uma forte classe média conservadora, constituída de agricultores. Cerca de 900.000 mil camponeses adquiriram o título de suas terras, venderam-nas e depois abandonaram a aldeia, enquanto que os mais prósperos ou empreendedores aumentaram o tamanho de suas explorações (Sanz-Pastor, 1988, p. 21).

A tentativa do governo czarista de desestruturar o avanço das comunas é analisada por SanzPastor que adota um tom crítico em relação a este processo, defendendo que as terras adquiridas pelos camponeses deveriam permanecer nas mãos do Estado ou da própria Comuna, atribuindo aos camponeses apenas a exploração destas terras:

Com isto pode-se notar como a colocação à venda de terras, que estejam em mãos mortas (Igreja, Estado, Comunas), costuma ser prejudicial. Talvez a forma mais aconselhável fosse o arrendamento aos agricultores, mas conservando a terra nas mãos do Estado ou da comuna, de tal maneira que não criassem estruturas de difícil evolução ou que se chegasse com o correr dos anos a uma nova concentração fundiária (Sanz-Pastor, 1988, p. 21).

Pois foi este o resultado gerado pelo enfraquecimento das Comunas, uma nova concentração fundiária no campo russo. As famílias mais numerosas e, consequentemente, com maior força de trabalho foram aos poucos concentrando às terras das famílias menores. Estas famílias de camponeses ricos eram conhecidas como kulaks. Com advento da revolução russa os bolcheviques permitiram que os camponeses ocupassem a terra.

O fermento e a base da Revolução Russa, como de quase todas as revoluções, foi o proletariado intelectual [...] Foram eles que dirigiram a revolução, empurrando e dominando o proletariado industrial e trazendo a reboque os camponeses por meio do apoio tático e suas demandas pequeno-burguesas por terras. A revolução prometeu aos camponeses a eliminação do controle oficial sobre a vida camponesa, o fim dos pagamentos de resgate e de servidão, menores impostos e distribuição da terra" (Sanz-Pastor, 1988, p. 22).

Todavia, a vontade dos revolucionários comunistas era a de nacionalizar todas as terras, posição contrária a dos camponeses que objetivavam o controle sobre seu território e os meios de produção. Oliveira, sobre este processo destaca que:

Iniciou-se assim, um processo de revoltas dos camponeses, que passaram a oporem-se aos novos métodos adotados pelo poder central soviético e que duraram até 1929. Deste ano em diante, foi feita a coletivização forçada dos camponeses que provocou a morte de mais de 12 milhões deles. Pela força o Estado soviético liderado por Stalin, dominou e passou a planificar sua agricultura. Os camponeses foram sendo convertidos em uma engrenagem a mais da vontade política do Estado soviético (Oliveira, 2007, p. 74). 
Em síntese a Reforma Agrária Russa foi um processo contraditório desde o inicio, no final do século XIX, até a revolução socialista, quando os camponeses foram subjulgados e obrigados a se adequarem a lógica do sistema socialista. Ao longo do século XX, sobretudo após a Segunda Guerra Mundial, outras Reformas Agrárias foram implementadas na Europa. Em geral foram reformas conservadoras com pequenas alterações na estrutura e no status quo predominante. Destacamos também a Reforma Agrária na Itália, a lei de "Stralcio", promulgada em 1950, determinou a expropriação de terras de propriedades com mais de 300 hectares que não cumpriam com sua função social. Uma das finalidades da Reforma Agrária na Itália foi assegurar a ocupação do território (região da Sardenha) e estimular a industrialização no Sul do país.

Na Ásia as Reformas Agrárias foram realizadas com o intuito de combater os aluguéis cobrados pelo arrendamento da terra. Os governos de vários países do continente se organizaram para combater os abusivos preços cobrados pelos proprietários. As Reformas Agrárias consistiram, basicamente, na regulação dos preços e na redistribuição de terra dos grandes latifundiários para os camponeses sem terra ou com pouca terra.

Na China, ao contrário do ocorrido na Rússia, a revolução partiu do campo para a cidade. A revolução neste caso foi precedida pela Reforma Agrária. Mao Tsé-Tung, líder da revolução chinesa, "deu-se conta de que era necessário adotar uma nova tática. Esta consistiu em considerar que o problema centra da Revolução Chinesa era o camponês, iniciando por isso os confiscos e a distribuição de terra" (Sanz-Pastor, 1988 p.25). Em meados da década de 1930 os camponeses marcharam rumo ao Norte do país, onde se estabeleceram e instauraram um processo reformista onde a terra era divida. O objetivo era criar uma nova classe média rural, que servisse como base de sustentação do processo revolucionário, os latifundiários e os camponeses ricos também receberam terras e um imposto progressivo sobre a terra foi criado para inibir o avanço da concentração da terra e do poder pelos camponeses ricos (Sanz-Pastor, 1988).

No Japão, pós Segunda Guerra Mundial, a Reforma Agrária foi conduzida pelo governo norteamericano. A reforma determinava que o governo japonês deveria apresentar um programa que garantisse a transferência das propriedades agrárias dos grandes proprietários para os rendeiros e proteção aos novos proprietários para que estes não voltassem a situação de rendeiros. A aquisição das terras (pelos rendeiros e agricultores sem-terra) era feita a partir da compra. Antes da reforma apenas $29 \%$ dos agricultores possuíam a terra que cultivavam após a reforma $70 \%$ dos agricultores se tornaram donos de suas terras.

$\mathrm{Na}$ África a questão agrária está centrada na concentração fundiária. Grande parte das terras agricultáveis do continente estavam e estão sob o controle de proprietários, em sua maioria de origem europeia. Com o fim do colonialismo europeu alguns países mantiveram a estrutura agrária herdada do colonialismo e outros países se dispuseram a combater a questão fundiária implementando a Reforma Agrária. Dos países que apostaram na Reforma Agrária destacamos os casos de Moçambique e Zimbábue.

Em Moçambique, após a guerra civil do final da década de 1970, o governo do presidente e líder revolucionário Samora Machel começou "discutir mudanças na política econômica, tais como a redução da importância dada aos grandes projetos agrícolas" (Oliveira, 2007, p. 91) a idéia era 
investir na formação de agroindústrias baseada nas pequenas propriedades. Após o processo de independência e da guerra civil o presidente Samora Machel, que tinha orientações socialistas, estatizou bancos e empresas transnacionais e serviços básicos como educação e assistência médica. A partir de 1986 assume a presidência Joaquim Alberto Chissano, nomeado após a morte de Samora Machel. Chissano interrompe o processo político que vinha sendo implantado e passa a implementar no país uma série de políticas neoliberais, "Em 1989, governo abandonou as orientações ideológicas marxistas leninistas e o caminho do socialismo, re-instituindo plenamente o capitalismo (Oliveira, 2007 p.91).

No Zimbábue a Reforma Agrária, de caráter mais conservador, tem inicio ainda na década de 1980 sob a tutela do presidente Robert Mugabe. Até o inicio da Reforma Agrária no pais as melhores terras estavam concentradas nas mãos de proprietários europeus, na sua maioria ingleses, e as terras menos férteis eram destinadas a população negra zimbabuana. Durante a década de 1990 com o avanço das políticas neoliberais a Reforma Agrária iniciada anteriormente já não respondia aos anseios e necessidades dos camponeses que iniciaram um processo de ocupações de terras em todo o país, legitimado por Mugabe. Oliveira destaca que:

Estas ocupações de terras passaram a aflorar a contradição básica do país herdada do passado colonial e racista: apenas quatro mil e quinhentas famílias brancas controlavam $75 \%$ das terras aráveis mais férteis e com chuvas mais regulares; enquanto isso mais de sete milhões de camponeses negros ficava com o restante [...] Mugabe passou a confiscar as fazendas dos brancos para assentar camponeses sem terra, mesmo contra as decisões da Suprema Corte que as julgava ilegais, ordenando suas remoções. O governo não voltou atrás e fez aumentar os recursos financeiros para continuar os assentamentos (Oliveira, 2007, p. 93).

Com a resistência do poder judiciário e aumento da pressão externar, de países vizinhos contrários aos avanços da Reforma Agrária em Zimbábue, Mugabe decidiu iniciar uma reformulação do poder judiciário e nas leis do país, para garantir a continuidade da Reforma Agrária no país.

Em seguida, substituiu 80\% dos juízes da Suprema Corte que reviu a decisão anterior e admitiu a legalidade da redistribuição dasterras dos brancos. Em novembro de 2001, nova lei foi assinada e determinou que qualquer fazenda tornava-seimediatamente propriedade do Estado quando recebesse o "aviso de aquisição", ou seja, o Estado poderia tomar aterra de fazendeiros se considerasse que esta não era produtiva ou se era muito grande para uma mesma família. OFMI, o Banco Mundial e a União Européia imediatamente cortaram os créditos ao Zimbábue. Em 2002, mais de 95\% das grandes fazendas dos brancos receberam os comunicados para desocuparem as terras em 45 dias e, no final daqueleano, praticamente os 14 milhões de hectares de terras tornaram-se disponíveis para os camponeses negros (Oliveira, 2007, p. 93).

A partir deste momento a Reforma Agrária avançou no país, mesmo com pressão e retaliações econômicas internacionais. O governo de Mugabe estruturou as instituições responsáveis pela Reforma Agrária e tem dado continuidade a este processo. 
Na América Latina, assim como na África, a concentração de terras é a grande mazela herdada do período colonial. Grande parte das terras eram e são controladas pelos herdeiros da elite colonial que dominavam os países latino-americanos. Vários países da América Latina experimentaram a Reforma Agrária ao longo do século XX. Destacamos os processos reformistas do México, Cuba e Chile.

No México, assim como na Rússia, a Reforma Agrária foi precedida Revolução Mexicana do inicio do século XX. A principais reinvidicações dos revolucionários, comandados por Emiliano Zapata, Pancho Villa e Pascual Orozco, era a realização da Reforma Agrária que garantisse a reestruturação das terras comunais, conhecidas como ejidos, pertencentes as comunidades indígenas. Entre 1915 e 1934 foram distribuídos pouco mais de 7 milhões de hectares. Os lideres revolucionários Zapata e Orozco, se rebeleram contra o governo de Madero e foram assassinados em 1915, Pancho Villa foi assassinado em 1923. A maio transformação agrária vivenciada pelo mexicanos ocorreu após a ascensão ao poder em 1934 do General Cárdenas que distribuiu em apenas 6 anos mais de 16 milhões de hectares. A maior parte dessas terras foram destinadas aos ejidos.

Em Cuba a Reforma Agrária também foi precedida pela Revolução de 1959. O governo revolucionário, comandado por Fidel Castro, promulgou a primeira lei de Reforma Agrária e deu inicio à distribuição das terras a qualquer cidadão cubano que se depusesse a trabalhar. $\mathrm{O}$ governo limitou em 400 hectares o limite da propriedade rural e em 27 hectares como o mínimo necessário a subsistência das famílias. Em 1963 o governo cubano aprovou uma segunda lei de reforma agrária que aumentou o controle das terras por parte do Estado Cubano, passando de $44 \%$ (1962) para 60\% (1963) e implantou o sistema de cooperativas produtivas seguindo o modelo da União Soviética. Sobre este processo Sanz-Pastor destaca que:

A Reforma Agrária cubana, como em todos os regimes socialistas marxistas, teve duas fases: na primeira uns $59 \%$ da propriedade ficou em mãos de particulares (repartindo um mínimo vital de terras aos pequenos agricultores), uns $12 \%$ em cooperativas e uns $29 \%$ em granjas do povo [...] Na segunda fase da Reforma, a agricultura estatal cresceu e as cooperativas, por se constituírem de terras de alguns poucos, foram levadas a decrescer (Sanz-Pastor, 1988, p. 33).

É interessante notar que ao longo do século XX, sobretudo após o fim da Segunda Guerra Mundial, os processos de Reforma Agrária, ao redor do mundo, foram muitos influenciados pela bipolaridade ideológica do período da Guerra Fria.

No Chile a Reforma Agrária foi impulsionada pelo governo conservador do presidente Jorge Alessandri (1958-1964) apoiado pelos Estados Unidos que queriam evitar os avanços dos ideais comunistas da revolução cubana. Entre 1964 e 1970, durante o governo do presidente Eduardo Frei Montalva, pouco mais de 3,4 milhões de hectares foram desapropriados e destinados a implantação de assentamentos rurais. O governo Frei aprovou a lei agrária que limitava o tamanho das propriedades em algumas regiões chilenas. Onde os solos tinha melhor qualidade a área máxima permitida era de 80 hectares, já nas regiões onde as condições do solo era menos 
favorável o limita das propriedades poderiam alcançar até 300 hectares. Somente as propriedades que ultrapassassem esses limites eram destinadas à Reforma Agrária.

No governo de Salvador Allende, entre 1970 e 1973, mais de 6 milhões de hectares foram desapropriados e destinados a Reforma Agrária. Allende visou também a distribuição dos recursos investindo em projetos de irrigação que beneficiassem a maioria dos agricultores camponeses. Com o golpe militar comandado por Augusto Pinochet, o processo de Reforma Agrária foi interrompido no país. Jacques Chonchol, que teve participação direta no processo de Reforma Agrária chileno, na composição do governos Frei e Allende, destaca em entrevista concedida a Alfredo Bosi em 1994 que na ditadura militar chilena "A reforma foi brutalmente interrompida".

No entanto, restou uma conquista que me parece ainda válida: a estrutura latifundiária, que durante séculos oprimira o camponês chileno, não mais se recompôs. E verdade que a junta militar devolveu uma parte das terras a fazendeiros que as reclamaram quando sobreveio o novo regime. E algumas famílias, desamparadas pelo governo militar, sem crédito nem equipamentos, precisaram vender suas terras a particulares, em geral, comerciantes e militares ávidos de aproveitarem da situação de desespero em que caíram os camponeses. Dos 10 milhões de hectares já expropriadose redistribuídos nas gestões de Frei e Allende, cerca da terça parte foi devolvida ou mercadejada. Mas o grande passo já tinha sido dado: a hegemonia do latifúndio improdutivo não mais voltou. Temo que a liberalização selvagem em curso no Chile atual entregue um excesso de terras a consórcios madeireiros exportadores que vão tomando lugar dos produtores de alimentos. Quando à qualidade de vida do povo não é critério para nortear a política econômica, o pior sempre pode acontecer (Chonchol, 1994, p. 256).

A seguir, apresentamos um quadro com a síntese de outros processos de Reforma Agrária que ocorreram ao redor do mundo durante o século XX, a tabela é baseada nos estudos de Carli, 1985; Brasil, 1952; Bornstein, 1982; Sanz-Pastor, 1988.

Tabela 1. Reforma Agrária pelo mundo no século XX

\begin{tabular}{l|l|l}
\hline Ano & País & Características \\
\hline 1939 & Colômbia & $\begin{array}{l}\text { Lei 200/1939 que estabelecia uma espécie de usucapião sobre a } \\
\text { propriedade privada. A terra pertenceria as pessoas que trabalhassem por } \\
\text { um período de 5 anos contínuos. }\end{array}$ \\
\hline $\mathbf{1 9 4 0}$ & Índia & $\begin{array}{l}\text { Reforma Agrária realizada, majoritariamente, pela redistribuição das } \\
\text { terras dos zamindari, propriedades estabelecidas em fins do século XIX, } \\
\text { quando a Companhia das Indias Orientais converteu o direito dos } \\
\text { coletores de impostos em direitos de propriedade agrária. As terras } \\
\text { desapropriadas eram indenizadas pelo Estado. As indenizaços eram } \\
\text { calculadas de acordo com a renda liquida dos antigos proprietários. }\end{array}$ \\
\hline $\mathbf{1 9 4 1}$ & Porto Rico & $\begin{array}{l}\text { Foi estabelecida a lei que criou a sociedade pública "Land Authority" que } \\
\text { tinha como objetivo explorar grandes extensões de terras e repartir uma } \\
\text { parte dos lucros entre os trabalhadores, disseminando com isso o conceito } \\
\text { de propriedade comunal. A Reforma Agrária de Porto Rico concebia a } \\
\text { terra como fonte de vida, de dignidade e de liberdade econômica, para os }\end{array}$ \\
\hline
\end{tabular}




\begin{tabular}{|c|c|c|}
\hline & & $\begin{array}{l}\text { homens e mulheres que nela trabalham, cada pessoa que trabalhe à terra } \\
\text { deve ser a dona da terra que a sustenta. }\end{array}$ \\
\hline 1941 & Turquia & $\begin{array}{l}\text { Tinha como objetivo proporcionar terras aos camponeses turcos, ajudar- } \\
\text { lhes a adquirir equipamentos essenciais e garantir a exploração continua } \\
\text { dos recursos agrários do país. A Reforma Agrária turca tinha outras } \\
\text { preocupações, além da distribuição de terras aos camponeses sem-terra, } \\
\text { como, por exemplo, a fertilidade do solo que dependia da organização do } \\
\text { regime da propriedade e dos tipos de lavouras implementadas. }\end{array}$ \\
\hline 1951 & Bolívia & $\begin{array}{l}\text { Decreto de lei que teve como objetivo restituir terras às coletividades das } \\
\text { aldeias, fornecendo-as aos camponeses, com a condição de que as } \\
\text { cultivassem, e expropriando os grandes domínios territoriais. }\end{array}$ \\
\hline 1952 & Egito & $\begin{array}{l}\text { Legislação que estabelecia o limite máximo das terras agrícolas em } 84 \\
\text { hectares. Algumas exceções foram permitidas para que sociedade e } \\
\text { associações, particulares (que se dispusessem a beneficiar terras não } \\
\text { irrigáveis e não passiveis de desapropriação) e sociedades industriais, } \\
\text { agrícolas, cientificas e de beneficência possuíssem mais de } 84 \text { hectares. }\end{array}$ \\
\hline 1952 & Guatemala & $\begin{array}{l}\text { Em } 1952 \text { foi aprovada a lei de Reforma agrária que visava eliminar os } \\
\text { resquícios de feudalismo; eliminar as formas de servitude; promover a } \\
\text { emancipação econômica da população pobre; promover a distribuição de } \\
\text { crédito e de assistência técnica pública aos agricultores assentados. }\end{array}$ \\
\hline 1954 & Vietnã & $\begin{array}{l}\text { Em } 1954 \text { os vietnamitas derrotaram os colonizadores franceses que } \\
\text { dominavam o país desde } 1850 \text {. Após o fim do processo revolucionário o } \\
\text { Vietnã foi dividido em duas partes o Norte (controlado pelos comunistas } \\
\text { vitoriosos) e o Sul (onde predominava um regime anticomunista } \\
\text { amparado pelos Estados Unidos). No norte, com a derrota dos franceses, } \\
\text { as terras dos latifundiários foram tomadas e distribuídas entre os } \\
\text { camponeses pobres. }\end{array}$ \\
\hline 1956 & Argélia & $\begin{array}{l}\text { O resultado das revoltas de } 1956 \mathrm{fez} \text { com que a França entregasse o } \\
\text { controle político da Argélia aos insurretos. Apesar de ter saído vitoriosa a } \\
\text { metrópole francesa se cansou de sustentar os colonos e os militares que } \\
\text { viviam em território argelino. O governo que triunfou depois da revolução } \\
\text { introduziu uma espécie de socialismo moderado nacionalista, que admitia } \\
\text { a propriedade privada da terra. }\end{array}$ \\
\hline 1979 & Nicarágua & $\begin{array}{l}\text { Reforma agrária baseada da desapropriação das terras que estavam } \\
\text { concentradas, principalmente, nas mãos das famílias Somoza, deposta } \\
\text { pela revolução Sandinista. A Reforma agrária num primeiro momento } \\
\text { desapropriou propriedades inteiras modernas e bastante tecnificadas e } \\
\text { capitalizadas que foram transformadas em empresas estatais chamadas } \\
\text { Áreas de Propriedade do Povo-APP's. }\end{array}$ \\
\hline
\end{tabular}

Fonte: Organização própria.

\section{ATUALIDADE DA REFORMA AGRÁRIA NO BRASIL}

Até o momento, vimos que a Reforma Agrária pode ocorrer, ao menos, de duas formas, são elas: A Reforma Agrária Conservadora, que é uma operação negociada entre antigas e novas forças 
sociais com o intuito de sanar questões pontuais através da utilização de instrumentos estatais. Na reforma conservadora o Estado tenta evitar ao máximo o conflito com interesses dos capitalistas. Esta reforma foi a implementada pelos governos brasileiros ao longo do século XX e nestas primeiras décadas do século XXI. Este possibilidade de reforma engloba a segunda categoria proposta por García (1973) - Reforma Agrária Convencional- e os dois primeiros tipos possíveis de transformações propostos por Silva (1971) - simples instrumentos de políticas e modificações nas estruturas existentes. Ao analisar "a Reforma Agrária que o governo Lula fez e a que pode ser feita", Fernandes (2012) destaca o entrave a realização da Reforma Agrária vai além da luta contra a concentração fundiária. Para ele é necessário eliminar a hegemonia do agronegócio:

Mas para implantar a reforma agrária é preciso muito mais que a desconcentração fundiária, é imprescindível eliminar a hegemonia do agronegócio sobre as políticas de desenvolvimento da agropecuária e reconhecer a importância das diferentes relações de produção, como a familiar, a associativa e a cooperativa (Fernandes, 2012, p. 1).

A outra possibilidade é a Reforma Agrária Estrutural, que consiste em grandes transformações das estruturas, precedida ou sucedida por um processo revolucionário liderado por novas forças sociais, fundamentada na modificação radical das relações de poder de uma determinada sociedade e nas normas institucionais que as sustentavam. Este tipo de Reforma é central nas reivindicações dos movimentos socioterritoriais brasileiros, que em maior ou menor grau, defendem uma ruptura com o sistema capitalista.

Nestas duas primeiras décadas do século XXI, a discussão em torno da Reforma Agrária tem sido polarizada por dois debates principais. O primeiro diz respeito a existência, ou não, de uma Questão Agrária, que justifique a realização da Reforma Agrária, o segundo diz respeito a intensificação da regularização fundiária em detrimento das desapropriações de terras na implantação da Reforma Agrária pelos governos brasileiros, pós ditadura militar.

Alguns autores como o sociólogo Zander Navarro e o engenheiro agrônomo Francisco Graziano Neto (Xico Graziano) ou políticos como a senadora Kátia Regina de Abreu (PFL/DEM, PSD) defendem que a Reforma Agrária não é mais necessária, ou não tem mais tanto sentido, no país. Outros como, o também sociólogo, José de Sousa Martins entendem que a Reforma Agrária deva ser uma questão resolvida pontualmente, que responda a necessidade apenas de uma parcela da população, o que ele considera como demanda real da Reforma Agrária. No campo favorável a Reforma Agrária encontram-se autores como o geógrafo Bernardo Mançano Fernandes e o economista Plinio de Arruda Sampaio. Estes defendem uma existência, e o agravamento, da Questão Agrária e considera a Reforma Agrária uma etapa necessária para o desenvolvimento territorial do país. Não queremos com este trabalho fixar ou determinar o território imaterial destes autores, nosso intuito nessa parte é analisar o discurso atual, destes que são os principais interlocutores favoráveis e contrários a implantação da Reforma Agrária no Brasil.

Navarro afirma que é a Reforma Agrária é "uma mera política governamental e, desta forma, uma ação do Estado que é marcada pelas diferentes conjunturas do desenvolvimento social vivido por determinado país" para ele é óbvio que "reformas agrárias não são políticas 'imutáveis' ou supra- 
históricas, imunes à passagem do tempo, ou não afetadas pelas transformações econômicas e sociais" (Navarro, 2008, p. 34).

Na perspectiva de Navarro os processos de expansão econômicos experimentados nas duas últimas décadas, associados às transformações sociais decorrentes, tornaram esta política de muito difícil consecução pelo Estado. O autor crítica aqueles que insistem na viabilidade da Reforma Agrária, taxando inclusive, parte considerável deles, como presos no tempo:

Insistindo em sua "viabilidade" no Brasil, mas sem oferecer flexibilidade interpretativa, parte considerável de nossa literatura sobre o tema ainda mantém seu locus analítico nos anos sessenta, sem conseguir perceber mais amplamente as mudanças sociais e econômicas verificadas no Brasil. Em consequência, fruto desta acrítica perspectiva que ignora as mudanças do período contemporâneo, não se percebe que, senão a "morte da reforma agrária", pelo menos vigora a sua clara desnecessidade na maior parte do território nacional, essencialmente porque não existe mais demanda para a sua implementação, na maior parte das macro-regiões brasileiras (Navarro, 2008, p. 35).

Para afirmar que não existe mais demanda para sua implementação Navarro se baseia na tese suscitada por Martins da demanda real, que afirma ser inexistente público que justifique uma Reforma Agrária a nível nacional. A demanda real é, de acordo com Martins, a soma das famílias dos acampamentos espalhados pelo país. Martins compreende que:

Em termos reais, a efetiva demanda por reforma agrária é constituída pelos sessenta mil sem-terra acampados nas ocupações. É evidente que isso não quer dizer que o problema social da terra se limite a eles. Mas, são eles que expressam acima de qualquer dúvida uma demanda por reforma agrária urgente (Martins, 2000, p. 108).

Para o ele é "inútil dizer que há 4,5 milhões de famílias sem-terra em todo o Brasil, se apenas cerca de sessenta mil assumem essa identidade. Isso é o que conta politicamente" (Martins, 2000, p. 108). Aceitar esta visão, apresentada por Martins e defendida por Navarro, é, por exemplo, a título de comparação, o mesmo que dizer que a demanda pela Reforma Urbana está centrada apenas nos milhares famílias acampadas nas periferias das cidades, organizadas ou não em movimentos de luta pela moradia, como o MTST. Se este pressuposto fosse correto as mais de 7,9 milhões de famílias que compõe o déficit habitacional do país e que vivem, em sua grande maioria, em áreas de risco iminente à vida, não necessitariam de políticas públicas como a Reforma Urbana, para sanar seus problemas. Portanto a ideia suscitada por Martins, que serve para a defesa das teses de Navarro, constitui-se em um argumento limitado e reducionista, utilizada na tentativa de desqualificar a luta pela Reforma Agrária e desconsiderando as mazelas inerentes ao avanço do capitalismo agrário.

O argumento de Navarro que atrela à demanda a necessidade da Reforma Agrária é refutado por Sampaio, que afirma que "A presença de um grande contingente populacional vivendo no campo 
em condições de grande precariedade revela a persistência e gravidade da questão agrária na sociedade brasileira" (Sampaio, 2012, p. 1) para ele "Não obstante as evidências de uma grave crise social no campo, o pensamento conservador insiste em desconstruir a questão agrária. Nos teóricos mais apaixonados do novo ruralismo, tal esforço assume forma caricatural" (Sampaio, 2012, p. 2). Ele complementa, nos explicando que:

[...] a questão agrária constitui [...] um problema que não pode ser desvinculado dos obstáculos que impedem a formação de estruturas econômicas, sociais, políticas e culturais de um Estado nacional autodeterminado. Por essa razão, a reforma agrária constitui elemento estratégico da luta do povo brasileiro para superar as relações internas e externas responsáveis pela dupla articulação que perpetua o regime burguês [...] Nessa perspectiva, a tarefa primordial da reforma agrária consiste em criar as condições objetivas e subjetivas para que todos os brasileiros que vivem no campo [...] possam participar em condições de relativa igualdade dos frutos do progresso propiciado pelo desenvolvimento das forças produtivas (Sampaio, 2012, p. 7).

Sampaio corrobora com a tese de Fernandes (2012), sobre a conflitualidade existente entre os modelos de desenvolvimento e a necessidade do enfrentamento que propicie a realização da Reforma Agrária:

A realização da reforma agrária pressupõe a presença de forças sociais capazes de mobilizar força suficiente para vencer a resistência dos grupos econômicos e sociais que resistem à mudança do status quo. Sob a liderança do latifúndio e das grandes empresas agro-industriais, a reforma agrária é combatida de maneira sistemática e implacável pelos segmentos da sociedade que dependem da super exploração do trabalho no campo e na cidade (Sampaio, 2012, p. 7).

Martins atrela a definição e a necessidade da Reforma Agrária a atualidade e concepção da questão agrária. Para ele "num país em que o grande capital se tornou proprietário de terras, a concepção clássica da questão agrária, e das reformas que ela pede, fica substancialmente alterada. São essas alterações que propõem as condições e os limites da reforma agrária no país". Esta afirmação corrobora com a tese de Fernandes de que a Reforma Agrária é reflexo da conjuntura e da correlação de forças da sociedade. E é justamente o poder do grande capital, enraizado na concentração das terras, que dificulta a realização da Reforma Agrária. A Reforma Agrária é antônima a está estrutura, e esta estrutura, hegemônica, é que dificulta sua realização.

Para Martins a questão agrária, em termos clássicos, está centrada no "bloqueio que a propriedade da terra representa ao desenvolvimento do capital, à reprodução ampliada do capital" (Martins, 2000, p. 99). A Reforma Agrária neste sentido serviria para desatar os nós que impedem o desenvolvimento e a reprodução ampliada do capital, mas como no Brasil este mesmo capitalismo, paradoxalmente, está baseado na concentração fundiária, uma reforma que se coloque contra à concentração seria uma reforma contra o capital. 
Alguns autores destacam que a Questão Agrária adquiriu novos elementos que perpassam à concentração fundiária, processos como a estrangeirização e o avanço dos agrocombustíveis, que colocam em cheque nossa soberania territorial e segurança alimentar (Fernandes, Welch e Gonçalves, 2012) a legalização da grilagem (Oliveira, 2011) e o avanço predatório socioambiental do agronegócio (Cubas, 2012; Bombardini, 2012) são elementos atuais da Questão Agrária, que fazem da Reforma Agrária, reformulada dentro deste novo contexto, uma demanda atual com novos desafios e enfrentamentos.

Existe dentro paradigmas, discursos que numa primeira impressão podem ser considerados contraditórios, mas que na verdade estão carregados de intencionalidade, como no artigo publicado pela senadora Kátia R. de Abreu, que credita a morosidade na implantação da Reforma Agrária as forças políticas de esquerda. No texto A esquerda não quer a reforma agrária, publicado pelo Jornal o Estado de São Paulo, ela defende que o principal obstáculo a sua realização é o MST, curiosamente o movimento que nas últimas décadas se tornou o principal movimento de luta pela terra e por Reforma Agrária no país:

O MST, braço rural do PT, não quer a reforma agrária, mas sim a tensão agrária, de preferência com cadáveres em seu caminho, de modo a dar substância emocional a um discurso retrógrado e decadente. Reforma Agrária não e postulado ideológico, é imperativo do desenvolvimento sustentado. Por isso a CNA a apóia. Por isso o MST e a esquerda fundamentalista não a querem (Abreu, 2010, p. A2).

É nítido no discurso da senadora, uma das maiores interlocutoras do agronegócio no Brasil, uma das estratégia adotadas pelo Paradigma do Capitalismo agrário, que consiste na desqualificação dos sujeitos contrários a lógica de desenvolvimento defendido por eles. Em outro texto Abreu (2012 a, p. A3) destaca o heroísmo econômico do capitalismo agrário, em seu ponto de vista "O Brasil tem no agronegócio o setor mais dinâmico de sua economia e o principal fator de segurança de suas contras externas" A senadora destaca, em mais um artigo publicado, que:

Todo o processo de mobilidade social em nosso país, que permitiu o surgimento e o progresso de diferente classes sociais, maior transferência de renda e o acesso a bens e produtos de consumo, se deve, fundamentalmente, à estabilização e barateamento dos preços de alimentos. Foram o acesso à tecnologia e a difusão do conhecimento cientifico aplicado à agricultura que evitaram, todos esses anos, carestia, crise de abastecimento e ameaça à estabilidade política. Ao gastarem menos para alimentar as famílias, urbanas e rurais, puderam viver melhor (Abreu, 2012 b, p. B14).

Esta é a base da retórica do paradigma do Capitalismo Agrário, em uma ponta desqualifica o movimento camponês, e na outra exalta os êxitos alcançados pelo capitalismo, como se a agricultura brasileira, apesar da hegemonia do capital, fosse uniforme. Abreu ignorou o Censo Agropecuário de 2006 que nos revelou que a agricultura familiar é a responsável pela maior parte da produção de alimentos no país e pelo emprego dos trabalhadores rurais. Esta agricultura, 
destacada pelo Censo é refutada pela senadora, que a considera atrasada, quando defende que a agricultura camponesa necessita ter "acesso à tecnologia e modernizar" para que se elimine "o arcaico que ainda persiste em várias regiões" (Abreu, 2012 b, p. B14).

Navarro e Graziano Neto seguem a mesma linha de raciocínio de Kátia R. de Abreu, afirmando que:

A agricultura se transformou, mas manteve seus produtores, o que foi uma façanha. Não houve concentração fundiária, tampouco devastação.Ainda estão preservados, cobertos com vegetação nativa, $61 \%$ do território nacional [...] Surpreende a crítica retrógrada que resiste à realidade, supondo nossa agricultura como na época latifundiária. Sem a pujança do campo,com sua elástica oferta de alimentos e matérias primas,a sociedade não teria se urbanizado;nem a economia teria progredido, perdendo-se em suas crises, incluindo a superinflação. $\mathrm{O}$ superávit agrícola paga as importações industriais.Os empregos gerados nas agroindústrias espalhadas pelo interior aquecem o comércio e ajudam a criar a classe média que faz prospera naturalmente a nação (Navarro e Graziano Neto, 2012, p. 139-140).

Na visão apresentada, por esses autores, não existe separação entre o agronegócio capitalista e a agricultura familiar camponesa. E essa é mais uma estratégica, muito conveniente para o capital, que utiliza os resultados alcançados pela agricultura camponesa para justificar o seu modelo de desenvolvimento. Ou seja, quando o agronegócio necessita se reafirmar, perante a sociedade, como moderno e avançado, utiliza como contraponto a agricultura familiar camponesa considerada pelos seus interlocutores como "arcaica e atrasada", mas quando é necessário justificar sua hegemonia política e econômica, os resultados alcançados pela mesma agricultura "arcaica e atrasada", com a produção de alimentos para os brasileiros, são glorificados. Neste sentido o Censo de 2006 foi elucidativo, representando uma afronta a essa intencionalidade do paradigma do Capitalismo Agrário, ao separar agricultores familiares e não familiares.

A tese da modernidade do agronegócio, derivada dos avanços tecnológicos do setor, é refutada por Sampaio, que baseado nos ensinamentos de Celso Furtado sobre o padrão de reprodução da agricultura brasileira, nos explica que o moderno e avançado agronegócio tem como base de sustentação as mesmas estruturas do passado:

É preciso esclarecer que a resistência à democratização da terra não se atém aos interesses estritamente ligados ao latifúndio improdutivo. O latifúndio produtivo - a grande empresa agrícola moderna - também depende de uma estrutura fundiária concentrada, que bloqueia o acesso do homem pobre a terra, e, em consequência, de um regime legal, que assegure a total disponibilidade das terras aos imperativos da exploração do capital agrário. O problema relaciona-se com o fato de que o caráter itinerante da agricultura subordinada ao agronegócio supõe a presença de grandes reservas de terras seja para repor as terras degradadas seja para abrir novas fronteiras de expansão dos negócios seja ainda como simples reserva de valor (Sampaio, 2012, p. 9-10). 
Sampaio ressalta que o avanço tecnológico não é suficiente para o desenvolvimento deste modelo agrícola, o capitalismo agrário no Brasil está, e sempre foi, assentado na concentração fundiária e na necessidade de expansão da fronteira agrícola. Para ele:

A reforma agrária polariza a luta de classes entre dois pólos opostos: de um lado, o latifúndio e seus cúmplices incondicionais - as burguesias brasileiras, o imperialismo e todos os segmentos da pequena burguesia que se beneficiam de privilégios aberrantes; e, de outro, os pequenos proprietários, os arrendatários pobres, os posseiros, os trabalhadores assalariados, os trabalhadores temporários, os sem terras, enfim, todos os homens do campo que vivem de seu próprio trabalho e seus aliados - os trabalhadores urbanos, empregados e desempregados. Em suma, a luta pela terra é um problema de classe. A vitória da reforma agrária depende de mudanças de grande envergadura que desatem a dupla articulação responsável pela perpetuação do padrão de acumulação e dominação do capitalismo dependente (Sampaio, 2012, p. 12-13).

Sampaio (2012) defende que "é urgente a necessidade de uma profunda crítica à teoria e à prática que fundamentaram a luta pela reforma agrária no último período" (p. 39), para ele "A reforma agrária não pode se ater à reivindicação das terras improdutivas sem colocar em questão o caráter socialmente perverso e ambientalmente predatório das terras produtivas. Cubas (2012) em seus estudos sobre a disputa territorial entre camponeses e ruralista em São Paulo, indicou que o avanço do agronegócio é acompanhado pelo avanço da miséria nos municípios onde ele se territorializa e expande, Bombardi aponta que o avanço do capital, também é acompanhado pelo aumento do uso de agrotóxicos, sobretudo nas regiões onde as safras de commodities agrícolas são maiores. Bombardi, destaca o caráter arcaico e moderno da agricultura brasileira, dentro da perspectiva do PQA:

Notadamente, percebe-se a subordinação da agricultura brasileira ao capital internacional. Arcaico e moderno se fundem: intoxicação, doenças e mortes, são o outro lado da moeda desta "moderna agricultura" que demanda toneladas de agrotóxicos produzidos com tecnologia de ponta, pelas maiores transnacionais do setor químico mundial (Bombardi, 2012, p. 84).

Outro assunto que polarizou o debate sobre a Reforma Agrária, se refere as políticas de obtenção de terras utilizadas nos últimos governos. Martins, a respeito do governo FHC, destaca que:

De fato, a regularização fundiária no Brasil é, na maioria dos casos, legítimo ato de reforma agrária. Apenas quem não conhece a realidade social do campo pode supor que a regularização é mero ato administrativo sem maior alcance. A sofrida e sangrenta resistência dos posseiros à sua expulsão violenta da terra para beneficiar grileiros e latifundiários e viabilizar a política de consolidação da aliança da terra com o capital, fator de esvaziamento da reforma, impôs ao 
Estado brasileiro nos anos mais difíceis e repressivos da ditadura a necessidade de atenuar e redefinir parcialmente o seu projeto fundiário. Foi o que salvou o país de se transformar num território de enclaves do poder absoluto do capital latifundista. Esquecer disso ou não saber disso, desqualifica qualquer análise pretensamente crítica da reforma agrária em andamento. A regularização da situação fundiária dos posseiros de extensas regiões do país foi e é um legítimo ato de reforma agrária porque impõe limites ao processo expropriatório que daria ao país uma estrutura fundiária muito mais concentrada e latifundista do que a atual.(Martins, 2000, p. 106-107).

Para Martins:

A reforma agrária é um tema político que se propõe em termosqualitativos e não em termos quantitativos. Não é o número de desapropriações ou o número de assentamentos em terras desapropriadas ou compradas que definem o perfil da reforma agrária brasileira, sua justeza ou não. $\mathrm{O}$ essencialé que haja um setor ponderável da sociedade reivindicando a ampliação do lugar da agricultura familiar no sistema econômico e que em parte essa agricultura familiar esteja nas mãos de pessoas que se ressocializaram na luta pela reforma agrária e nela se politizaram (Martins, 2000, p. 109).

Fernandes ressalta que não devemos "desconsiderar que a realização da reforma agrária necessariamente deva desconcentrar a estrutura fundiária, já que um de seus objetivos é democratizar o acesso a terra por meio da distribuição territorial" (Fernandes, 2012, p. 4). Entretanto ao considerarmos a Reforma Agrária, somente, ou principalmente, a partir das desapropriações chegaremos a conclusão de que este processo no país foi de caráter conservador "pelo fato de a maior parte das terras terem sido regularizadas, ou seja eram terras de posseiros que passaram a ser assentados ou eram terras públicas ou griladas que foram regularizadas" (Fernandes, 2012, p. 4). Não ocorreu no país um enfrentamento direto contra as bases do capitalismo agrário, assentado, principalmente, na concentração fundiária. Sampaio nos explica, a partir de um ponto de vista radical, onde classifica a Reforma Agrária brasileira como neoliberal, que esta nunca teve como objetivo modificar a estrutura fundiária, apresentando também um posicionamento contrário a prioridade dada a regularização fundiária, que teria sido utilizada como estratégia do Estado para amenizar a conflitualidade no campo brasileiro.

Na realidade, o objetivo da reforma agrária neoliberal nunca foi modificar a estrutura fundiária do país, mas apenas empurrar o problema para frente, afastando o risco imediato de uma conflagração no campo, pelo isolamento dos homens pobres em regiões remotas do país. A finalidade oculta - depositar os homens pobres longe da civilização mantendo-os dispersos uns dos outros - foi bem sucedida [...] Ao reduzir o programa fundiário à mera distribuição de lotes de terra e a providências de regularização da propriedade dos posseiros, ignorando propositalmente a necessidade de dar ao assentado assistência técnica, comercial e financeira, os beneficiários da reforma agrária na sua grande maioria nunca superaram o estado de penúria e extrema instabilidade, permanecendo 
sempre vulneráveis aos ataques do latifúndio e da especulação fundiária (Sampaio, 2012, p. 31-32).

Ao tratar das políticas de obtenção de terras Navarro afirma que a Reforma Agrária foi descaracterizada nos últimos anos, quando o Estado passou a investir na compra de terras em detrimento das desapropriações:

Sobre este pano de fundo mais geral, no entanto, em anos ainda mais recentes, na presente década, cada vez com maior frequência, o Estado brasileiro tem reduzido suas ações de desapropriação e tem realizado especialmente compras de imóveis para formar os novos assentamentos, pois em face da modernização produtiva estão escasseando aqueles imóveis passiveis de serem arrecadados compulsoriamente para o programa de reforma agrária sob os ditames da Lei. Portanto, menos ainda estamos falando de reforma agrária e, mais, de uma política estatal de compra de terras para fins de formação de novos assentamentos rurais (Navarro, 2008, p. 37).

A visão de Navarro ignora os estudos sobre as políticas de obtenção de terras (Martins, 2001; Rocha, 2009; Santos, 2010; Coca, 2011; Fernandes, 2012), que nos mostra que a regularização fundiária tem se destacado como uma das principais políticas de Reforma Agrária no país. Navarro afirma ainda que este processo, intensificado na região Amazônica, deixa de lado possíveis implicações ambientais e transforma a Reforma Agrária em uma ação regional:

O que se chama atualmente no Brasil de reforma agrária apresenta inúmeras contradições e dificuldades de toda ordem. Sobressaem, contudo, dois aspectos que imputam ao processo uma dimensão farsesca. Inicialmente, o fato de a ação governamental ter se concentrado, neste período de recente aceleração, em desapropriar ou comprar terras especialmente na região Norte do país. Deixando de lado implicações ambientais (embora sejam estas cada vez mais graves e urgentes), esta preferência geográfica, de fato a opção que restou, em face dos altos preços das terras em outras regiões, está transformando a reforma agrária, na prática, em uma ação regionalizada (Navarro, 2012, p.,37-38, grifo nosso).

Navarro ignora também o posicionamento de Martins (2000) que havia nos atentado que o processo de intensificação da Reforma Agrária no Norte do país, visa solucionar os problemas dos posseiros e povos tradicionais da região. A grande maioria destes territórios da Reforma Agrária, foram criado justamente para responder as implicações ambientais causadas pelo modelo de desenvolvimento do capitalismo. Se espalham pela região Reservas extrativistas, Florestas Nacionais, Assentamentos e Reservas de Desenvolvimento Sustentável, entre muitas outras alternativas criadas para conciliar o desenvolvimento das famílias, que dependem tradicionalmente da natureza, com a preservação do meio ambiente. A seguir traçamos um panorama dos resultados da Reforma Agrária no Brasil desde o governo Sarney até o segundo governo Lula. 


\section{A REFORMA AGRÁRIA BRASILEIRA: DE SARNEY A LULA}

No Brasil o caminho percorrido pela Reforma agrária, principalmente, após o processo de redemocratização, tem como característica principal a luta pela terra e a implantação de assentamentos rurais. O I PNRA, elaborado durante o governo Jose Ribamar Sarney e o II PNRA, elaborado em 2004 durante o governo Luís Inácio Lula da Silva foram uma tentativa de dinamizar a implantação de assentamentos e a criação dos territórios da Reforma Agrária. Vale ressaltar que o contexto histórico, em que estes planos foram elaborados, eram favoráveis a implantação da Reforma agrária, sendo o primeiro durante o processo de redemocratização do país e o segundo na eleição de um presidente de esquerda, comprometido com as causas sociais e a luta de classes. No entanto, ambos os planos ficaram aquém do estipulado, como destacamos na tabela 2.

Tabela 2. Brasil. Planos de Reforma agrária e famílias assentadas

\begin{tabular}{lll}
\hline Planos de Reforma agrária & Aprovado & Realizado \\
\hline PNRA I 1985 - 1989 & 1.400 .000 & 125.377 \\
PNRA II -2003-2006 & 1.050 .000 & 223.724 \\
\hline
\end{tabular}

Fonte: DATALUTA - Banco de Dados da Luta Pela Terra, 2011; Rocha, 2008; BRASIL, 1986; BRASIL, 2004. Organizado por Herivelto Fernandes Rocha.

No I PNRA, foram beneficiadas pela Reforma agrária pouco mais de 125 mil famílias, muito abaixo da meta estipulada de mais de 1,4 milhões de famílias. No entanto, apesar da derrota política sofrida com as modificações da proposta original, o plano elaborado pelo governo acabou colocando a reforma agrária novamente na pauta de discussões políticas do país.

Nos governos de Fernando Collor de Melo (1990-1992) e Itamar Franco (1993-1994) foram beneficiadas pela Reforma agrária pouco mais de 63 mil famílias (tabela 3), o menor índice após o período de redemocratização do país. Este retrocesso da Reforma agrária se deve, principalmente, a forte repressão, por parte do governo Collor, contra os movimentos socioterritoriais com a invasão de secretarias e a prisão de lideranças destes movimentos em diversos estados. Esta atitude do governo causou um refluxo nas ações dos sem-terra, organizados, sobretudo no MST, restringindo o processo de luta e de territorialização dos assentamentos. O governo Itamar, marca a retomada do diálogo com os movimentos e a aprovação das leis que regulamentaram os artigos da Constituição de 1988, referentes a Reforma Agrária.

O governo do presidente Fernando Henrique Cardoso - FHC registrou os maiores índices da Reforma agrária no Brasil. Foram quase 400 mil famílias beneficiadas durante os oito anos de governo. $\mathrm{O}$ aumento da implantação de assentamentos rurais foi acompanhado pelo aumento da luta pela terra, através das ocupações, e por dois episódios, dos mais lamentáveis da história do nosso país - os massacres de Corumbiara em dezembro de 1995 e o de Eldorado dos Carajás em abril de 1996 - que colocaram transforma a Questão Agrária e a necessidade da Reforma agrária em uma das principais prioridades públicas do país, este fato fez com que o governo FHC 
acelera-se a implantação de assentamentos rurais, na tentativa de responder as pressões da sociedade e dos movimentos que se organizaram, aumentando, conseqüentemente, ano após ano os conflitos por terra em todo o país. Neste período a disputa entre os modelos de desenvolvimento se acirrou, como poucas vezes na história recente do país. Apesar da aceleração da criação de assentamentos e territórios da Reforma Agrária, “ a questão agrária se manteve, exatamente por causa de seu caráter estrutural" (Fernandes, 2008a p.79) e adentrou o Governo Lula na expectativa de ser amenizada.

Durante o governo Lula, foram beneficiadas pela Reforma agrária, em oito anos 276 mil famílias. O II PNRA que tinha como meta o assentamento de mais de 1 milhão de famílias em 4 anos, ficou muito abaixo da expectativa. Todavia, devemos ressaltar que durante o governo Lula, outras políticas públicas foram implantadas ou intensificadas como o PRONERA - Programa Nacional de Educação para a Reforma Agrária, PRONAF e o PAA - Programa de Aquisição de Alimentos. Isto demonstra que neste governo, o cerne principal da reforma agrária não foi apenas a implantação de assentamentos, que se deu em grande parte, na região Norte do país,mas também o fortalecimento do território camponês através da criação e intensificação das políticas públicas atreladas ao desenvolvimento do território camponês.

Tabela 3. Brasil. Reforma Agrária nos governos brasileiros. Anos 1985-2010

\begin{tabular}{lllllll}
\hline Governos & Assentamentos & $\%$ & Famílias & $\%$ & Área & $\%$ \\
\hline Sarney 1985 - 1989 & 825 & 10 & 125.377 & 15 & 8.358 .664 & 14 \\
Collor e Itamar 1990 - 1994 & 475 & 6 & 63.550 & 7 & 5.042 .335 & 8 \\
FHC 1995 - 2002 & 3.947 & 49 & 394.287 & 46 & 20.810 .876 & 33 \\
Lula 2003-2010 & 2.854 & 35 & 276.384 & 32 & 28.230 .258 & 45 \\
\hline Total & 8.101 & 100 & 859.598 & 100 & 62.442 .133 & 100 \\
\hline
\end{tabular}

Fonte: DATALUTA - Banco de Dados da Luta Pela Terra, 2011.

$\mathrm{Na}$ figura a seguir apresentamos a territorialização das famílias beneficiadas pela Reforma Agrária em todo o país, durante os governos Sarney e Lula.

Nota-se, na análise do mapa, uma grande concentração de famílias beneficiadas pela Reforma Agrária no Norte do país. Esta concentração é fruto da prioridade dada a regularização fundiária em detrimento da desapropriação de terras. As terras agricultáveis, nas outras regiões do país, em grande parte, já estão sob o controle territorial de um dos modelos de desenvolvimento, sobretudo do capital.

Além de garantir os direitos sobre a terra, dos povos tradicionais que habitam a região, a implantação de assentamentos no Norte é menos complicada, tendo em vista o elevado preço das terras, nas regiões dotada de infraestrutura. Também devemos levar em consideração que grande parte das terras, sobretudo dos estados que fazem parte da Amazônia Legal, ou são terras devolutas, pertencentes ao governo federal, estados ou municípios, ou são terras com títulos de propriedade duvidosos. Esta somatória de fatores, além da questão ambiental, justificam em parte o desenho do mapa apresentado. 
Figura 1. Brasil. Famílias Assentadas. 1985-2010

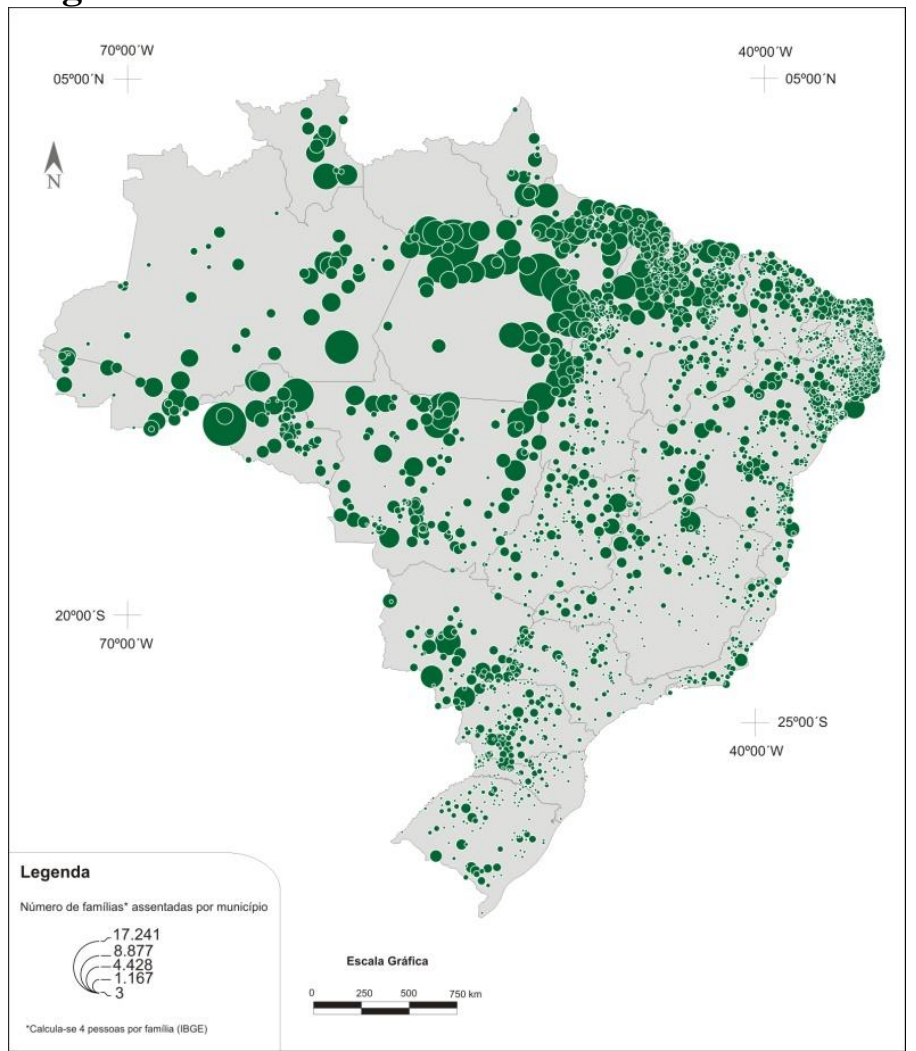

Fonte: DATALUTA, 2012. Organização própria

\section{DISPUTA TERRITORIAL: CAMPESINATO E AGRONEGÓCIO}

A questão Agrária, ou seja, os problemas agrários gerados pelo expansão e reprodução ampliada do capitalismo no campo, é , como já destacamos, inerente à conflitualidade entre diferentes paradigmas de desenvolvimento que disputam o controle territorial. Deste modo, a predominância de um modelo em detrimento do outro têm reflexos diretos na elaboração de políticas públicas e no desenvolvimento do país. Essa disputa gera territórios distintos a partir de relações sociais e de poder distintas. Para Fernandes esses modelos de desenvolvimento determinam a organização do espaço geográfico, por meio da produção de territórios, gerando e intensificando conflitualidades que são insolúveis por causa da hegemonia do modo capitalista de produção (Fernandes, 2008 b, p. 8).

Essa conflitualidade e predominância pode ser verificada quando analisamos, por exemplo, o volume de recursos destinados ao agronegócio e ao campesinato. No plano referente a safra de 2011/2012 o governo Dilma disponibilizou para o agronegócio (agricultura e pecuária) R \$ 107 bilhões, já para o PRONAF - Programa Nacional de Fortalecimento da Agricultura Familiar, foram destinados pouco mais de $\mathrm{R} \$ 16$ bilhões,ou seja, coube ao campesinato, apenas $15 \%$ do volume total de crédito destinado para o modelo predominante, o agronegócio.Vale ressaltar que o campesinato é responsável pela produção dos principais alimentos consumidos pela população 
brasileira.Destacamos a produção de mandioca com 87\%, feijão com 70\%, milho com 46\%, leite com $58 \%$, aves com $50 \%$ e $59 \%$ da produção de suínos.

Além da maior produtividade de alimentos é no campesinato que a maior parte dos trabalhadores rurais se encontram ocupados, com uma média de 15,3 trabalhadores a cada 100 hectares contra 1,7 trabalhadores a cada100 hectares ocupados no agronegócio (Censo Agropecuário, 2006). Somente na região Nordeste, o modelo camponês é responsável por $82,9 \%$ da ocupação de mão de obra no campo ${ }^{2}$.

Por isso, a Reforma agrária deve ser encarada como uma questão crucial para o desenvolvimento territorial do país, afinal é modelo produtor de alimentos e gerador de emprego e renda de grande parte da população rural. Ela deve ser compreendida e pensada a partir dos respectivos contextos nacionais e da correlação de forças existentes, considerando os objetivos estratégicos de desenvolvimento que contemplem a multidimensionalidade territorial. Infelizmente, o nosso contexto atual, é amplamente favorável ao modelo de desenvolvimento do capitalismo agrário.

Na tabela 4, apresentamos dados sobre a distribuição territorial brasileira baseados no Censo de 2006, onde podemos verificar como essa disputa, entre modelos de desenvolvimento, é desigual. O agronegócio utiliza 29,38\% de todo o território nacional para a produção, principal, de commodities agrícolas destinadas ao mercado mundial, enquanto o campesinato responsável pela produção de alimentos, está territorializado em $9,43 \%$ do território nacional, totalizando pouco mais de 80 milhões de hectares.

Tabela 4. Brasil. Distribuição territorial (área em milhões de hectares)

\begin{tabular}{lll}
\hline Territórios & Área & \% \\
Agricultura Familiar & 80,18 & 9,43 \\
Agronegócio & 249,77 & 29,38 \\
Indígenas & 125,55 & 14,77 \\
Urbanizada & 2,07 & 0,24 \\
Unidades de Conservação / Corpos d' Água & 83,56 & 9,83 \\
Outras ocupações & 308,51 & 36,30 \\
\hline Brasil & $\mathbf{8 5 0 , 0 0}$ & $\mathbf{1 0 0}$ \\
\hline
\end{tabular}

Fonte: Censo Agropecuário, 2006. Organização própria

$\mathrm{Na}$ figura 2, apresentamos um esboço da distribuição territorial entre os dois modelos de desenvolvimento do campo brasileiro.

\footnotetext{
${ }^{2}$ Banco do Nordeste, disponível em: www.bnb.gov.br/content/aplicacao/Pronaf/.../apresentacao.asp
} 
Figura 2. Brasil. Disputa Territorial e Agronegócio x Campesinato

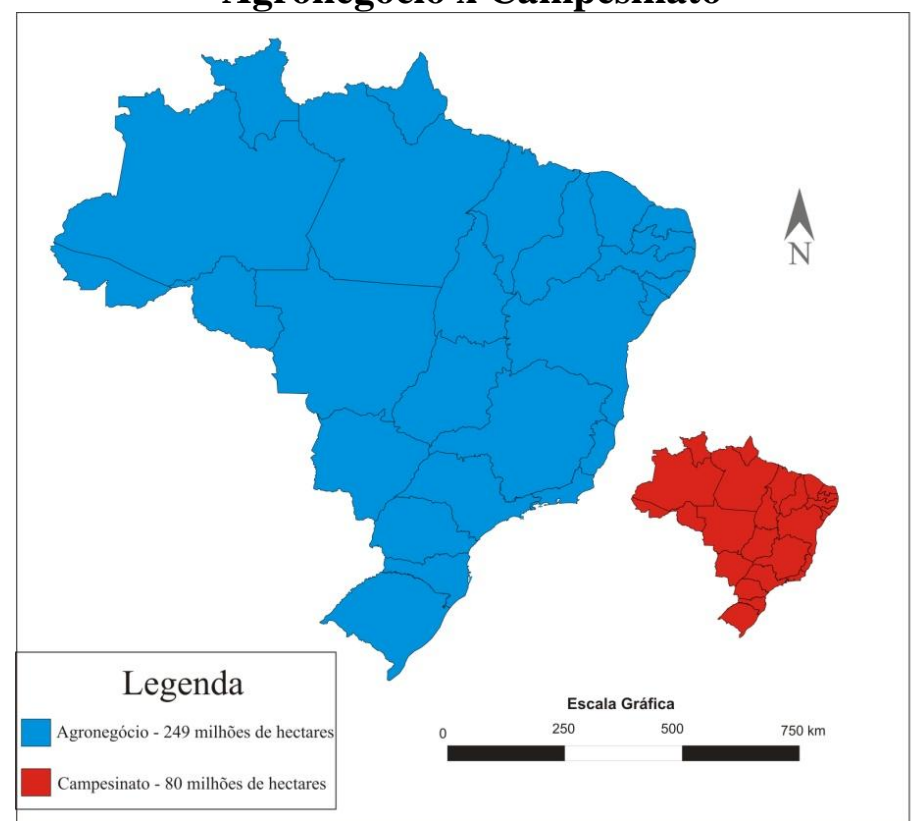

Fonte: Censo Agropecuário, 2006. Organização Própria.

A figura é muito didática e elucidativa, no sentido de que nos dá a real dimensão da desigualdade entre os modelos de desenvolvimento do campo brasileiro. A idéia é demonstrar o tamanho destes territórios, com se fossem verdadeiros países. O demonstrado na figura é apenas uma das dimensões onde do enfretamento entre o capitalismo agrário, que amparado em sua força política, economia e intelectual, e o campesinato se realiza de forma desigual.

A hegemonia do capital é clara e clara também é a vitória parcial dele sobre o campesinato, num jogo onde o que está em disputa é a soberania brasileira (alimentar, energética, territorial). A seguir tecemos algumas considerações sobre o que foi apresentado neste trabalho.

\section{ALGUMAS CONSIDERAÇÕES FINAIS}

Respondendo ao questionamento feito por Garcia, no inicio do artigo - qué se reforma, cómo se reforma y para qué se reforma - entendemos que o território brasileiro, historicamente marcado pela concentração fundiária marcado atualmente pela intensificado da Questão Agrária, é o que deve ser reformado.

A Reforma agrária, portanto, deve ser pensada e realizada a partir do território. Esta reforma deve ter como premissa o desenvolvimento territorial, território do campesinato, em contraposição a hegemonia do capital. E é justamente essa hegemonia, política e econômica e até mesmo cultural - tendo em vista o que ocorreu no carnaval de 2013 no Brasil, onde uma das maiores empresas do 
agronegócio mundial, a BASF, patrocinou a escola de samba campeã, que retratou a vida simples do home do campo - a raiz da Questão Agrária no Brasil. Esta estratégia da multinacional visa fortalecer a idéia de que o agronegócio, causador de inúmeras mazelas no país, é o mesmo produtor de alimentos dos brasileiros. Nessa perspectiva, que o capital visa estabelecer, o agricultor familiar camponês e o empresário capitalista rural são a mesma coisa, personificados numa mesma figura.

A reforma agrária e o fortalecimento do território campesino é, neste contexto, uma necessidade urgente que contribui para manutenção, construção e consolidação de nossa soberania, diante do avanço do agronegócio favorecido pela disputa desigual - exemplificada na figura - entre modelos de desenvolvidos distintos, com interesses distintos. Enquanto o agronegócio e seu conglomerado de empresas utilizam o território brasileiro para especulação e produção de mercadorias voltadas para o mercado internacional o campesinato tem o compromisso com o local, produzindo alimentos em quantidade e qualidade para a grande maioria da população.

Por isso debater e discutir a necessidade, atualidade e sentido da Reforma Agrária é um exercido cada vez mais urgente. Dialogar e respeitar o ponto de vista contrário é fortalecer o nosso território imaterial e a nossa perspectiva, qualificando o debate e contribuindo, mesmo que parcialmente, com a reflexão a respeito de um tema tão premente no Brasil. As milhões de famílias brasileiras ou a demanda irreal da Reforma Agrária, necessitam de uma política que enfrente vá de encontro a hegemonia capitalista. Uma política adequada as suas reais necessidades e formuladas a partir das inúmeras realidades que temos num país de dimensão territorial e cultural como o nosso.

\section{REFERÊNCIAS BIBLIOGRÁFICAS}

ABREU, Kátia. A esquerda não quer reforma agrária. Jornal o Estado de São Paulo, 25 de maio de 2010, p. A2.

ABREU, Kátia. Agronegócio o setor moderno. Jornal o Estado de São Paulo, 04/09/2012 a, p. A3.

ABREU, Kátia. Arcaico e Moderno. Jornal Folha de São Paulo, 15 de setembro de 2012 b, p. B14.

BOMBARDI, Larissa M. Agrotóxicos e agronegócio: arcaico e moderno se fundem no campo brasileiro. In: Direitos humanos no Brasil 2012. Organização: MERLINO, Tatiana; MENDONÇA, Maria L. São Paulo: Rede Social de Justiça e Direitos Humanos, 2012, p.75-86.

BORNSTEIN, Claudio Thomás. A Reforma Agrária na Nicarágua. São Paulo: Editora Brasiliense, 1982.

CARLI, Gileno de. História da Reforma Agrária. Brasília: Gráfica Brasiliana, 1985.

CENSO AGROPECUÁRIO DE 2006. Rio de Janeiro: Instituto Brasileiro de Geografia e Estatística-IBGE, 2006, p. 1-146. 
CUBAS, Tiago E. A. São Paulo agrário: representações da disputa Territorial entre camponeses e ruralistas de 1988 a 2009. Presidente Prudente: Dissertação de Mestrado. UNESP/FCT/PPGG, 2012.

COCA, Estevan L. Um estudo da diversidade e atualidade da Reforma Agrária: análise dos tipos de assentamentos do território Cantuquiriguaçu - Estado do Paraná. Presidente Prudente: Dissertação de Mestrado. UNESP/FCT/PPGG, 2011.

DATATAlUTA - Banco de Dados da Luta Pela Terra. Coordenação: FERNANDES, Bernardo M. Presidente Prudente: UNESP/FCT/NERA, 2012.

DORNER, Peter. Reforma agrária e desenvolvimento econômico. [Tradução: Alvaro Figueiredo] São Paulo: Biblioteca 70 Economia, 1972.

FERNANDES, Bernardo M. O MST e as Reforma Agrárias no Brasil. Revista OSAL - CLACSO, outubro de 2008 a, ano IX, $n^{\circ} 24$, p. 73-85.

FERNANDES, Bernardo M. Entrando no territórios dos territórios. Presidente Prudente: NERA, 2008 b.

FERNANDES, Bernardo. M. Reforma Agrária e educação do campo no governo Lula. Revista Campo Território, agosto de 2012, vol. 7, nº 14, p. 1-23.

FERNANDES, Bernardo M., WELCH, Clifford A. e GONÇALVES, Elienai C. Políticas Fundiárias no Brasil. Uma análise géo-histórica da governança da terra no Brasil. Roma: Framingthe Debate Series, 2012, no 2.

GARCÍA, Antonio. Dinamica de las reformas agrárias em América latina (2 ${ }^{\text {a }}$ Edição). Santiago do Chile: ICIRA, 1967.

GARCÍA, Antonio. Sociologia de la Reforma Agrária en América Latina. Bogotá: Cruz de Sur, 1973.

CHONCHOL, Jacques. O Chile ontem e hoje. Revista Estudos Avançados [online], 1994, vol. 8, n 21 , p. 247-257. 〈http://dx.doi.org/10.1590/S0103-40141994000200016>.

MARTINS, José de S. Reforma Agrária, o impossível diálogo sobre a História possível. São Paulo: Revista Tempo Social, 2000, vol. 11, nº 2, p. 97-128.

NAVARRO, Zander. Nunca cruzaremos este rio. A estranha associação entre o poder do atraso, a história lenta e a sociologia militante, e o caso da reforma agrária no Brasil. Revista Redes, maio/agosto de 2008, vol. 13, n 2 , p. 5-51.

NAVARRO, Zander e GRAZIANO NETO, Francisco. Realidade agrária e ideologia. Brasília: Revista de Política Agrária, 2012, ano XXI, nº 2, p. 139-140.

OLIVEIRA, Ariovaldo U. Modo de Produção Capitalista, Agricultura e Reforma Agrária. São Paulo: USP/FFLCH, 2007. 
OLIVEIRA, Ariovaldo U. Não Reforma Agrária e Contra Reforma Agrária no Brasil do governo Lula. XIII EGAL - Encontro de Geógrafos da América Latina. Costa Rica, 2011. Disponível em: <http://www.egal2011.geo.una.ac.cr/index.php?option=com_remository\&Itemid=180\&func $=$ star tdown\&id=514 >.

ROCHA, Herivelto F. Análise e mapeamento da implantação de assentamentos rurais e da luta pela terra no Brasil entre 1985 e 2008. Presidente Prudente: Monografia. UNESP/FCT, 2009.

SAMPAIO, Plinio de A. Proposta de Plano Nacional de Reforma Agrária. Revista da Associação Brasileira de Reforma Agrária -ABRA, 2005, vol. 32, nº 1.

SANZ-PASTOR, Fernando. A Urgência da Reforma Agrária. Um Enfoque Histórico[tradução Antonio José de Almeida Meirelles]. São Paulo: Nerman, 1988.

SANTOS, Rafael de O. C. Estudo das políticas de obtenção dos assentamentos de reforma agrária no Brasil entre 1985 e 2009. Presidente Prudente: Monografia. UNESP/FCT, 2010.

SILVA, José Gomes da. A Reforma Agrária no Brasil. Rio de Janeiro: Zahar Editores, 1971.

(C) Copyright Herivelto Fernandes Rocha, 2013.

(C) Copyright GeoGraphos, 2013.

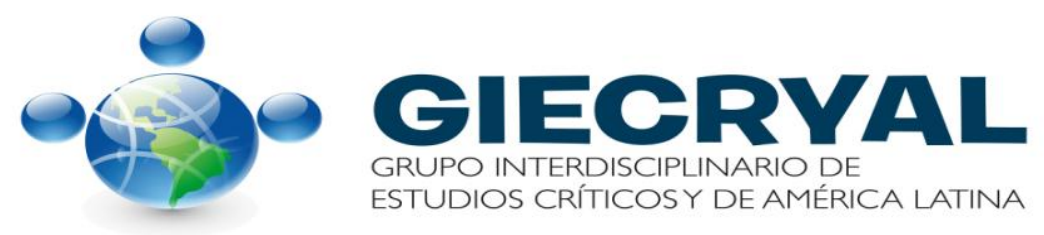

